\title{
ILLEGALLY-OBTAINED INCOME AS A STRUCTURAL COMPONENT OF SHADOW PROCESSES IN THE ECONOMY
}

\author{
Natalija Berlach ${ }^{1}$, Oleksandr Kulyk ${ }^{2}$, Sergii Losych ${ }^{3}$
}

\begin{abstract}
The study of shadowing processes in the economy is an integral part of the methodological knowledge, aimed at forming the security environment of the world community, its development on the way to overcoming crisis situations in the economy, politics, and society. This being said, it is difficult to overestimate the role of the state in determining appropriate approaches to assessing the results of such activities, justifying the selection of certain current methods of influencing public relations in the economic field in order to ensure their functioning within the legal framework. Drawing empirical conclusions and recommendations in this article are aimed at substantiating the links between the result of economic activity and economic activity as such, which determines the characteristics of welfare and well-being of a person, his/her enrichment. Thus, the formation of a cognitive social link between human welfare, emotional factors, and the economic crisis situation in the state has a common denominator, which makes it possible to assess the level of economic development of the country as a whole, to identify processes of shadowing of the economy, provided that illegally-obtained income is determined in its structure. Coming up with "regulatory filters" that allow synthesizing the object (illegally-obtained income), at which measures for detecting and transforming it into the legal economic field are aimed, it is possible to achieve a real result in counteracting the shadowing of national economies. Certain measures currently being taken at the level of national legal systems in this area should be compatible with those adopted by the European Union and, at least, as stringent as other measures applied at the international level. The specified determines the necessity to search for optimal ways of defining the concept of illegally obtained income, its place and role as a structural component of shadow processes in the economy. Methodology. The solution to the set goal is realized using the cognitive potential of the system of philosophical, general scientific and special methods. Analysis and synthesis allowed identifying the signs of illegal income, the shadowing of the economy, counteracting the shadow economy, and forming the last concept. Methods of grammatical review and interpretation of legal norms contributed to identifying gaps and other shortcomings of legislation on problems of ensuring counteraction to the legalization (laundering) of illegally-obtained income, developing proposals for its improvement, in particular, regarding the specifics of defining the meaning of the concept of "illegally obtained income" in domestic legal framework, the relationship of this concept with other economic and legal concepts. The comparative legal method allowed determining the development directions for domestic normative acts in order to bring them in line with the generally accepted European standards.
\end{abstract}

Key words: income, shadow economy, shadowing of economy, money laundering, legalization of income, economic crimes, unlawful enrichment.

JEL Classification: E64, O15, P24

\section{Introduction}

Reducing the scale of the shadow economy is an integral part of the strategy of reforming any legal state of the world and a pledge of promoting a system of guarantees for the decent development of man and citizen. Achieving high social security standards with the recognition of the priority of balancing national and individual interests, free economic development, is possible only on condition that each member of the society is aware of his/her role in preventing illegal activity in the sphere of economy and other areas that are recognized as components of national security of the country. This being said, it is difficult to overestimate the role of the state in determining appropriate approaches

\footnotetext{
Corresponding author:

${ }^{1}$ State Research Institute of Ministry of Internal Affairs of Ukraine, Ukraine.

E-mail: 40natalija@gmail.com

${ }^{2}$ State Research Institute of Ministry of Internal Affairs of Ukraine, Ukraine.

E-mail: alexgkulik@ukr.net

${ }^{3}$ Donetsk Law Institute of the Ministry of Internal Affairs of Ukraine, Ukraine.

E-mail:1sv300sv@gmail.com
} 
to assessing the results of such activities, justifying the selection of certain current methods of influencing public relations in the economic field in order to ensure their functioning within the legal framework.

In this regard, it is understandable that scientists from different countries of the world are interested in identifying such key indicators of the level of economic security of the country as the level of shadowing of its economy, which should be calculated based on generally accepted methods, taking into account the peculiarities of the formation and development of national economic and legal doctrines.

Undoubted is a provision formulated by the Nobel Prize winner D. North who devoted a series of papers to the analysis of transformational economies of postSoviet countries, regarding the fact that the economy and finances of countries that adopted formal rules of the game, developed under other economic and financial systems, were doomed to failure from the very beginning. Moreover, the so-called "shock therapy" and hasty, unconsidered privatization destroyed not only the old (planned) economic system but also the main motivational incentives for development, led to unprecedented corruption at all levels of power and criminalization of society. The most acute contradictions have appeared in the institutes of financial and credit sphere, which caused high rates of inflation and galloping depreciation of national currencies, imbalances of state budgets and balance of payments, and were accompanied by the collapse of investment programs and a high level of shadowing of the national economy (Savych, 2014).

Recognizing the state of economic shadowing as an indicator of economic security, it is obvious that the task of determining the structure of the economy's shadowing is also determined, taking into account the changes and trends of macro- and microeconomic processes. At the same time, it is indisputable that the definition of the content of each structural element should be clearly defined, which will ensure the quality of observation, analysis, relevant calculations, and the authenticity of the results. Such a definition needs to be consolidated at the level of a legal act.

\section{Identification of signs and structural components of the shadow economy}

According to the said thesis, it should be noted that in Ukraine, the definition of the shadow economy is proposed in the Methodological Recommendations for Calculating the Level of Shadow Economy, approved by the Order of the Ministry of Economic Development and Trade of Ukraine № 123 as of February 18, 2009. In this by-law, the shadow economy is recognized as the economic activity of an economic entity that is not registered in the established procedure, which is characterized by minimizing the cost of production of goods, performance of works, and provision of services, evasion of taxes, fees (obligatory payments), statistical questionnaires, and submission of statistical reporting, the result of which is a violation of the established norms (the level of minimum wage, the length of working time, conditions and safety of work, etc.) (Order of the Ministry of Economy of Ukraine № 123, 2009). Such a definition generates many discussions and observations on the deficiencies of the formulated features, which do not allow specifying, which of them are key, which will allow distinguishing such activity from other economic activities. Moreover, if we assume that the main characteristic of the shadow economy is economic activity itself, then it would be logical to expect methods of calculating the level of the shadow economy on such a basis in the said document.

However, the first of these methods, called "direct" and the one used to calculate macroeconomic parameters of the shadow economy, relates to the calculation of the level of the shadow economy by the method of "population expenditure - retail trade turnover" and is to identify the existence of an excess of consumer cash expenditures on the purchase of goods over the total volume of sales to the population by all economic entities in the legal sector of the economy (Order of the Ministry of Economy of Ukraine № 123, 2009). This method is based on the comparison of specific indicators of "cash expenses" and "amounts of monetary turnover", which leads to the conclusion that the amount of the excess of costs relates to such characteristics of economic activity as shadow. The analysis of other methods also allows us to conclude on such a necessary sign of the shadow economy as a "result" of economic activity, which in fact is the main goal of the implementation of such an activity and an indicator that allows setting the volume of the shadow economy. Accordingly, the following characteristics of economic activity: "unregistered in an established manner" resulting in "violation of the established norms" should be extended in relation to the description of its results. As a rule, such results are referred to as "revenues", "funds" and so on.

One should agree with the thesis that the scale and conditions for realization of certain types of economic unregistered activities, which in most of the still valid laws and regulations and scientific works are attributed to the so-called "productive part" of the shadow economy, are to be substantially modified today. Actually, it needs to be reviewed, especially in the theory, what exactly should be attributed to this "productive part". Previously, as an example, the results of households, tutoring, etc. were often presented. Today, such economic activity is regulated and its results make up a significant part of the population's income (Tylchyk, 2017). Among the factors hampering growth in countries such as Ukraine, Kazakhstan, Brazil, Russia, the World Bank names badly deteriorated household balances. Also, the World Bank pointed to a transport blockade of uncontrolled 
territories in the Donbas, which led to weak data of industrial production (The World Bank has improved the forecast of Ukraine's GDP growth in 2018).

Accordingly, it is possible to determine economic performances of households as a part of the shadow economy only if it is implemented in violation of legal requirements. Such violations may have signs and be qualified as: civil, property, disciplinary, administrative, criminal. Depending on the composition of the offense to be established, measures are taken to influence the offender concerned. Actually, for the specified types of offenses, it is proposed to carry out gradation of measures of influence in order to stop the spread of shadow processes in the economy. The most widespread among them are: measures of property liability/liability for damage, administrative influence, including administrative responsibility, the most severe are measures of criminal law influence, involving the bringing of persons to criminal liability.

It should be noted that some scholars point out that the shadow economy - the economic activity associated with tax evasion, the types and methods of tax evasion are both forms and ways of concealing the "shadowing" of activity (Nesterova, 2008). Others - focus on the requirements of the United Nations System of National Accounts (1993), according to which the economic activity is an activity that meets the following requirements:

- firstly, it is carried out with the aim of obtaining an economic benefit from the production and sale of goods and services;

- secondly, the activity is possible if there is a certain solvent demand for the goods and services being produced;

- thirdly, all agreements between sellers and buyers are concluded by mutual agreement (the United Nations System of National Accounts, 1993).

Accordingly, it is proposed to exclude criminal activity and its results from the shadow economy, arguing that there is no sign of voluntary agreements between entities, which is contrary to the recognition of such activity as an economic one (Cheremisina, 2007).

This thesis once again indicates the absence of a single approach to defining the concept of "shadow economy", as well as its structure, methods of calculation, related to the complexity of the phenomenon, the peculiarities of its genesis in different countries. However, summing up the numerous discussions, the attention is drawn to the need to consider that most of the program documents, reports from both domestic and international experts, international monitoring organizations contain provisions that the shadow economy is the basis of a complex, organized multilevel system, which includes money laundering, and the whole shadow infrastructure that provides for its functioning (legislative, judicial, political, ideological, cultural, ethical, system of values and codes of conduct) actively influences the state of the shadow processes.
As an example, the following data is available: as of May 2013, according to estimates by the international association OXFAM, losses in the form of tax revenues to the budgets of countries around the world amounted to more than 156 billion USD, which is twice the amount needed to end poverty. Ukrainian companies do not actually trade in direct contracts with direct importers of domestic products and use offshore zones to generate profits abroad. From 2012 to September 2015, only four main trading countries with low tax jurisdiction (Switzerland, Virgin Islands, Great Britain, and Cyprus) account for about $64 \%$ of exports of cereals and oilseeds, as well as products of their processing, $44 \%$ of exports of ferrous metals and products of them, and $61 \%$ of exports of ore and energy products; the volumes of potentially lost taxes only in the area of trade in grain and oil crops from 2012 to September 2015, according to assumptions, amount to $1.5-1.7$ billion USD that could be used to improve the socio-economic situation and innovative development of Ukraine (Kravchuk, 2016).

The above emphasizes the urgency of unifying the approaches to defining the concept of "shadow economy" taking into account the best ways to eliminate these inconsistencies, which lead to real inhibition of activities to ensure counteraction to shadow processes in the economy, in particular, legalization (laundering) of illegally obtained income, not only for the purpose of serving the national interests of Ukraine, but also of the whole world. In this definition, the characteristics of such features as economic activity and its results should be pointed out: income, money, etc. In terms of both the calculations and the formation of a system to counter the spread of shadow economic activity, it is required to indicate the unlawful nature of the activity, which leads to the formation of relevant results (revenues, funds).

\section{Defining the state policy directions on the prevention of money laundering}

Each state determines the priority directions of ensuring that the said incomes fall into the legal circulation and bringing to justice the persons committed crimes in the economy by shadowing it. Studying the experience of foreign countries, it is possible to state that attention is paid to countering the legalization (laundering) of illegally obtained income.

Measures taken at the level of the national legal systems in this field should be consistent with those adopted by the European Union and, at least, as stringent as other measures taken at the international level. In this direction, subjects of national systems for counteracting shadow economy are guided, in particular, by the FATF Recommendations and the instruments of other international bodies engaged in combating money laundering and terrorist financing in organizing and providing the said counteraction.

As for other types of offenses (civil, property, disciplinary, administrative, financial), it is necessary to 
state the absence of strategically defined approaches in the individual countries (including Ukraine) about the comprehensive impact on the persons who commit them.

In the aspect of taking into account the positive experience, one should point out that in the Republic of Belarus, the Law "On the Bodies of Financial Investigations of the State Control Committee of the Republic of Belarus" as of 16.07.2008 is in force that, among the tasks of the financial investigation authorities, provides for the protection of the interests of society and the state from criminal and other illegal encroachments in the sphere of economy, ensuring economic security of Belarus, investigation of criminal cases, administration of the administrative process in accordance with the competence of the bodies of financial investigations (Law "On the Bodies of Financial Investigations of the State Control Committee of the Republic of Belarus", 2008). That is, attention is focused not only on crimes, as well as the counteraction to the legalization of the proceeds from their commission, but also on other types of offenses, which make up a significant part of the shadow economy.

It is worth mentioning also about the approach used by the policy maker of the Lithuanian Republic. It meets the requirements of the FATF Guidelines on Anti-Money Laundering and Anti-Terrorist Financing, while in the provisions of delegated legislation devoted to the characterization of financial investigations in the Republic of Lithuania, the possibility is provided without collecting data about the criminal origin of income, but having established that the property of a person whose value exceeds the amount fixed in the legislation, in particular, 500 minimum subsistence levels, is not proportional to his/her legal income, to decide on the launch of a pre-trial investigation, a suspicion of wrongdoing under Article 189-1 (Illegal enrichment), and the implementation of measures of procedural influence in order to ensure the confiscation of property or extended confiscation (Order "On Recommendations for Financial Investigations”, 2013).

\section{Conclusions}

An example of another approach to ensuring the impact on the shadow processes, in relation to dealing with the proceeds received by an illegal but not criminal way, is the proposals and adoption of the Laws on their "legalization" the introduction into official circulation. Such an approach is supported not by all scholars and ordinary citizens but is occasionally initiated and implemented.

So, we can quote suggestions from individual scholars and politicians in Ukraine regarding the so-called "legalization of income". In particular, the authors of the draft Law "On Amendments to the Tax Code of Ukraine (regarding the legalization of property in connection with the voluntary declaration of property status and undeclared personal incomes)" indicate that in connection with the need to unshadow the economy of Ukraine in general and property relations in particular, return private capitals to the economy and fill the budget of Ukraine, the legalization of property should be introduced in connection with voluntary declaration of property status and undeclared personal incomes. The Institute for similar legalization of incomes (zero declaration, tax, economic, financial amnesty, etc.) since the end of the XX century is used periodically in many countries - the USA, Belgium, Germany, Italy, France, Sweden, Switzerland, Kazakhstan, Latvia, and so on. Usually it is implemented, firstly, with the purpose of establishing a sort of relationship between the state and taxpayers, and secondly, to increase budget revenues and increase the volume of legal investments into the economy (Draft Law, 2017).

The above proposals are not new, there have already been attempts of a similar nature; it is worth mentioning the "tax compromise" in Ukraine that did not bring the expected results. Therefore, the need for a strategic definition of approaches to the complex impact on persons committing crimes and other types of offenses (civil, property, disciplinary, administrative, financial) in the field of the economy, which results in the formation of incomes of illegal origin and increase in the size of the shadow economy, is urgent.

\section{References:}

Savych, I. V. (2014). Determinants of the formation of the shadow economy of Ukraine. Young Scientist, 12(15), 87-92.

On Approval of Methodical Recommendations for Calculating the Level of the Shadow Economy: Order of the Ministry of Economy of Ukraine on 18 February 2009 № 123. Ministry of Economic Development and Trade of Ukraine. Retrieved from: http://www.me.gov.ua/LegislativeActs/Detail?lang=uk-UA\&id=4bb297a0-c900-404f$8 \mathrm{c} 6 \mathrm{f}-5 \mathrm{f} 76 \mathrm{f} 18 \mathrm{~b} 1503$

Tylchyk, O. (2017). Administrative and legal provision of counteraction to shadow economy: the monograph. Publishing House "Helvetica". Kyiv.

The World Bank has improved the forecast of Ukraine's GDP growth in 2018. Retrieved from: http://tyzhden.ua/ News/193890

Nesterova, N. V. (2008). Shadow economy and tax evasion. Management of Economic Systems: Electronic Scientific Journal, 1(13). Retrieved from: http://uecs.mcnip.ru

The United Nations System of National Accounts (1993). Retrieved from: https://unstats.un.org/unsd/ nationalaccount/sna.asp

Cheremisina, N. V. (2007). Statistic measurement of the shadow economy: regional aspect: thesis for Dr. Sc. (Economics). Samara. 
Kravchuk, O. V. (2016). Alternative mechanisms of socio-economic development of Ukraine. Centre for Social and Labour Studies.

Law "On the Bodies of Financial Investigations of the State Control Committee of the Republic of Belarus" on 16.07.2008. Retrieved from: http://base.spinform.ru/show_doc.fwx?rgn=23925

Order of the Prosecutor General of the Republic of Lithuania "On Recommendations for Financial Investigations" on 19 March 2013. Retrieved from: https://censor.net.ua/news/238090/litva_gotova_podelitsya_s_ukrainoyi_ opytom

Draft Law of Ukraine "On Amendments to the Tax Code of Ukraine (regarding the legalization of property in connection with the voluntary declaration of property status and undeclared personal incomes)". Retrieved from: http://w1.c1.rada.gov.ua/pls/zweb2/webproc4_1?pf3511=61891 